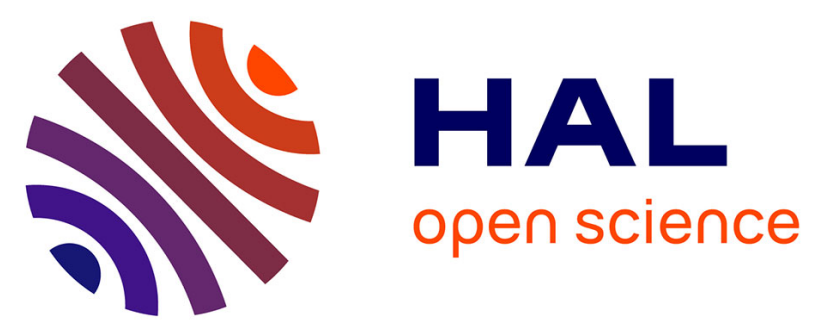

\title{
Matthew Anderson, 2015, A History of Fair Trade in Contemporary Britain: From Civil Society Campaigns to Corporate Compliance, Houndsmills, Basingstoke, Hampshire UK, Palgrave Macmillan, 230 p.
}

Gavin Fridell

\section{To cite this version:}

Gavin Fridell. Matthew Anderson, 2015, A History of Fair Trade in Contemporary Britain: From Civil Society Campaigns to Corporate Compliance, Houndsmills, Basingstoke, Hampshire UK, Palgrave Macmillan, 230 p.. Review of Agricultural, Food and Environmental Studies, 2016, 97 (4), pp.267269. $10.1007 / \mathrm{s} 41130-016-0028-\mathrm{z}$. hal-03114836

\author{
HAL Id: hal-03114836 \\ https://hal.science/hal-03114836
}

Submitted on 19 Jan 2021

HAL is a multi-disciplinary open access archive for the deposit and dissemination of scientific research documents, whether they are published or not. The documents may come from teaching and research institutions in France or abroad, or from public or private research centers.
L'archive ouverte pluridisciplinaire HAL, est destinée au dépôt et à la diffusion de documents scientifiques de niveau recherche, publiés ou non, émanant des établissements d'enseignement et de recherche français ou étrangers, des laboratoires publics ou privés. 


\title{
Matthew Anderson, 2015, A History of Fair Trade in Contemporary Britain: From Civil Society Campaigns to Corporate Compliance, Houndsmills, Basingstoke, Hampshire UK, Palgrave Macmillan, 230 p.
}

\author{
Gavin Fridell $^{1}$
}

Published online: 2 December 2016

(C) INRA and Springer-Verlag France 2016

In A History of Fairtrade in Contemporary Britain, Matthew Anderson offers an engaging, thought-provoking, rigorously investigated, and genuinely original treatment of fair trade in Britain - the leading fair trade market in Europe - that is a must read for academics and practitioners concerned with fair trade, consumer politics, social movements, and trade justice more widely. Anderson's book is designed to fill gaps in the growing body of works on fair trade, which tend to focus on Southern impacts with some general research on the North, and can be situated broadly within various works aimed at rethinking the history and social context of consumer politics and the "ethical consumer" (Byrne and Sharpe 2014; Fine 2013; Richey and Ponte 2011; Goodman 2010; Trentmann 2008).

Anderson's work offers three important contributions to the study and understanding of fair trade. First, based on extensive research on archival and unpublished documents, Anderson offers a rigorous historical investigation of fair trade in Britain in the post-war era, aimed at uncovering the motivations of fair trade companies and organizations, and a diverse array of social movements that have played key roles in fair trade's development. Anderson provides careful institutional narratives that offer new insights around Oxfam's original "commercial" goals (Chapter 1); the often under-appreciated role played by Christian ethics in fair trade (Chapter 2); the reluctance of the cooperative movement (Chapter 3 ) and the Trade Union Congress (TUC) (Chapter 4) to support fair trade initially due to their focus on the needs of Northern consumers

Gavin Fridell

Gavin.Fridell@smu.ca

1 International Development Studies, Saint Mary's University, 923 Robie Street, Halifax, NS B3H 3C3, Canada and workers, concerns around the fair trade model (including fair trade's often thin support for collective bargaining), and the difficulties involved in constructing genuine internationalist movements.

Second, Anderson's work offers a new approach to understanding fair trade consumerism, aimed at developing a theory of change that places less emphasis on individual consumer behavior than on "collective consumption, public procurement, and corporate compliance" (1). Anderson challenges the popular assumption that consumer demand drives the emergence and evolution of projects like fair trade, pointing instead to the key roles played by social movement actors, nongovernmental organizations, campaigners, commercial intermediaries, and alternative trade organizations. While consumer demand matters, Anderson argues that these actors have been the central drivers in motivating consumer and corporate behavior, employing the discourse of ethical consumption to "find common ground, and a shared language, with which to engage multiple stakeholders on issues of trade and development" (108).

Third, drawing on his historical and social approach, Anderson offers a rethinking of scholarly and popular understandings of the history of fair trade. He is particularly concerned with accounts of fair trade that have argued that the movement initially had a more radical orientation from the 1950 s to the 1980 s, including aspirations to support a New International Economic Order (NIEO) and state policies around "trade not aid". These arguments, Anderson argues, overlook the ways in which fair trade from the very start was focused at "micro-level trade interventions" aimed at "practical action and direct engagement with producers and communities in the South" (12-14).

Challenging the conventional narrative around the historical evolution of fair trade, Anderson states that many initiatives in the 1960 s were driven by the commercial concerns of 
charitable organizations in need of funding for their initiatives. The fair trade model based on providing fair prices, pre-financing, longer-term contracts, and producer dividends or social premiums did not emerge until the 1970s. By the 1980s and 1990s, fair trade organizations began to pursue mainstreaming, giving up "introspection" and the search for the " socially ideal" trade system" while remaining connected to fair trade's "goodwill and practical experience" (109). By the 2000s, fair trade had been thoroughly mainstreamed, with over two-thirds of fair trade products in Britain sold by mainstream companies, and the alternative terminology had been more or less abandoned.

Anderson effectively applies this general narrative to specific cases of fair trade companies, alternative trade organizations, campaigners, supporters, and detractors. What I found most compelling was his chapter on Oxfam, long viewed as a "benchmark to consider contemporary questions about 'authentic' or 'alternative' Fair Trade" (24). To Anderson, much of the discussion around Oxfam has been based on an overly simplified and idealized portrayal of Oxfam's early trading years. True to the "founding myth" of Oxfam trading, the organization did begin selling pincushions made by Chinese refugees seeking asylum in Hong Kong in the 1950s, which evolved into its Helping by Selling (HbS) program in 1967 (25). However, Anderson argues that throughout the 1950s and 1960s, Oxfam's primary concern was to provide employment for Third World producers, under working conditions akin to any conventional company or multinational corporation, and to raise funds to pay for its relief and development work. When Oxfam did create a separate trading company, it was not out of fair trade idealism but a mixture of commercial concerns and strategic steps to avoid possible ramifications over its charitable tax status under UK law.

It was not until the 1970s, argues Anderson, that Oxfam began to take seriously issues and ideas that many would today consider "fair trade." Out of concern from some in the organization that Oxfam trading had become too focused on profits, a separate Oxfam Bridge was created, aimed at a "fair" return for work, with dividends from profits directed back to producer groups. Even then, as Oxfam shops continued to grow throughout Britain, they were often reluctant to stock products from Oxfam Bridge, concerned with more profitable items - in 1985, only 389 out of 777 Oxfam shops stocked Oxfam Bridge products (33). Throughout the 1980s and 1990 s, Oxfam played a key role in founding fair trade organizations and companies, including Cafédirect, today the fifth largest coffee brand in the UK. This reflected a turn away from handicrafts, previously seen as an important additional income for small producers, especially women, and toward "cash crops" and conventional markets that some within the organization sought to resist. By 2002, Oxfam ceased selling its own fair trade products, recognizing the limits of fair trade products and wanting to focus more on advocacy work aimed less at accessing mainstream markets than at changing the structural conditions under which global markets function.

Anderson's reworking of the history of fair trade is important and highly instructive; it adds nuance and complexity to the understanding of fair trade's historical development. At the same time, I would argue that the common narrative around the changing nature of the political idea or ideological fantasy of "fair trade" remains accurate - from the 1950s to the 1970s, the idea of fair trade encapsulated a wider political project aimed at a radical reforms to the existing economic order, promoted by an array of governmental and nongovernmental groups in the "Third World"; after the 1980s and the emergence of fair trade labeling, the dominant idea of fair trade changed, and it became associated with what it is today: ethical shopping. What Anderson's work deftly challenges is the extent to which leading fair trade organizations were involved in the wider political battles of the 1950s and 1960s. Instead, Oxfam comes off not as having "changed" its main orientation in the 1980s but rather as having taken the lead at the start in developing a new version of "fair trade" aimed at producerconsumer linkages and practical impacts at a "human scale" (12).

At the same time, Anderson does maintain that organizations like Oxfam did change in the 1980s and 1990s. He argues that Oxfam eventually grew to realize that it could not attain through fair trade its ambition of offering "a genuine alternative to the increasingly dominant free trade, market-led ideology" (23). Yet, he argues that Oxfam in the 1960s was driven to a significant degree by commercial and practical considerations. In the 1970s, Oxfam and other groups developed the "new and distinctly modern approach to 'alternative trade' that incorporated the principles of 'fair prices', pre-financing, longer-term contracts, and producer dividends or social premiums" (15). Given that these principles, along with the focus on commercial and practical goals, remain central to fair trade today, it is not always clear what has changed and what "alternative" has been lost. Anderson suggests that it was primarily the "terminology" around alternative trade that was lost with the turn to mainstreaming (144). Overall, the narrative offered would seem to emphasize consistency over time in the goals and values of fair trade organizations as much, or maybe even more, than change.

In the final chapters of the book, Anderson explores the challenges and contradictions of ethical consumerism, locating fair trade as a "new social movement" distinct from traditional labor and consumer politics due to its ability to combine a diverse set of participants, at different times and for different reasons, under an array of claims around internationalism, Christian charity, social justice, solidarity, social entrepreneurialism, consumer politics, and moral duty. Anderson points to the contradictions of corporate involvement (for example, around Nestlé's commitment in 2005 to sell $0.02 \%$ of its coffee beans certified fair trade) (127), the positive but limited 
benefits of fair trade, and the unlikeliness that fair trade can bring about the structural changes required to address global inequality and insufficient producer incomes.

Given his focus on fair trade North and his desire to challenge the storyline of an "authentic" fair trade lost, Anderson does not provide a clear assessment on the extent to which he thinks fair trade is or is not effective at attaining trade justice. This allows him to focus his conclusions on the "practical" and "philosophical drivers" that have been central to fair trade's institutional and governance success in Britain. Rather than getting mired in longstanding debates over fair trade's effectiveness, Anderson focuses on fair trade as a movement, emphasizing its adaptability, resilience, and continuing relevance as it "edits" consumer choices (145). At the same time, by providing only a brief discussion (4-6) on fair trade's overall impact, Anderson's innovative narrative on the historical evolution of fair trade in Britain is not brought to bear as much as it could be on whether or not fair trade is something we should be "driving" for-what are the "opportunity costs" of devoting so much human energy and resources toward a project that has relatively modest benefits and, as Oxfam has increasingly recognized, can only achieve so much even if it was to be widely adopted. Recent research into the cocoa industry in Côte d'Ivoire, for example, suggests that the average Ivorian cocoa farmer would need to see their income increase by $400 \%$ to reach the poverty line (Fountain and Hütz-Adams 2015). This means that no version of fair trade certification could end poverty for Ivorian cocoa farmers, unless it was to increase farmer incomes significantly - unthinkable under the fair trade model.

Anderson's book, of course, cannot resolve the challenges and contradictions of fair trade and would be invaluable for anyone who wants to explore them further and rethink their meaning and origins. The book should be widely read and find its way onto many shelves and classrooms. It is a highly original work that provides a novel understanding of the contemporary history of fair trade that reveals fresh insights and new directions for further inquiry.

\section{References}

Byrne S, Sharpe E (2014) In pursuit of justice: Just Us! Coffee roasters Co-op and the fair trade movement. Black Point, Nova Scotia, Fernwood, $136 \mathrm{p}$.

Fine B (2013) Consumption matters. ephemera 13(2):217-248

Fountain AC, Hütz-Adams F (2015) Cocoa baromeer 2015, http://www. cocoabarometer.org/Resources_and_Data.html

Goodman MK (2010) The mirror of consumption: celebritization, developmental consumption and the shifting cultural politics of fair trade. Geoforum 41(1):104-116

Richey LA, Ponte S (2011) Brand aid: shopping well to save the world. University of Minnesota Press, Minnesota and London, $288 \mathrm{p}$.

Trentmann F (2008) Free trade nation. Oxford University Press, Oxford, $464 \mathrm{p}$. 